\title{
Analysis of Chemical Reaction Kinetics Behavior of Nitrogen Oxide During Air-staged Combustion in Pulverized Boiler
}

\author{
Jun Xia Zhang ${ }^{*}$, Jiang Feng Zhang² \\ ${ }^{1}$ School of Energy Engineering, Yulin University, Yulin City, Shanxi Province 719000, China \\ ${ }^{2}$ Northwest Electric Power Construction Company, Xian City, Shanxi Province, 710032, China
}

Received: $5^{\text {th }}$ November 2015; Revised: 14th January 2016; Accepted: $16^{\text {th }}$ January 2016

\section{Abstract}

Because the air-staged combustion technology is one of the key technologies with low investment running costs and high emission reduction efficiency for the pulverized boiler, it is important to reveal the chemical reaction kinetics mechanism for developing various technologies of nitrogen oxide reduction emissions. At the present work, a three-dimensional mesh model of the large-scale four corner tangentially fired boiler furnace is established with the GAMBIT pre-processing of the FLUENT software. The partial turbulent premixed and diffusion flame was simulated for the air-staged combustion processing. Parameters distributions for the air-staged and no the air-staged were obtained, including infurnace flow field, temperature field and nitrogen oxide concentration field. The results show that the air-staged has more regular velocity field, higher velocity of flue gas, higher turbulence intensity and more uniform temperature of flue gas. In addition, a lower negative pressure zone and lower $\mathrm{O}_{2}$ concentration zone is formed in the main combustion zone, which is conducive to the NO of fuel type reduced to $\mathrm{N}_{2}$, enhanced the effect of $\mathrm{NO}_{\mathrm{x}}$ reduction. Copyright (C) 2016 BCREC GROUP. All rights reserved

Keywords: Combustion; Pulverized coal; Air-staged; Chemical reaction kinetics mechanism of NOx

How to Cite: Zhang, J.X., Zhang, J.F. (2016). Analysis of Chemical Reaction Kinetics Behavior of Nitrogen Oxide During Air-staged Combustion in Pulverized Boiler. Bulletin of Chemical Reaction Engineering \& Catalysis, 11 (1): 100-108. (doi:10.9767/bcrec.11.1.431.100-108)

Permalink/DOI: http://dx.doi.org/10.9767/bcrec.11.1.431.100-108

\section{Introduction}

In recent years, with the rapid development of national economy and electric power industry, the large-scale coal-fired power plants have been increasing constantly. The $300 \mathrm{MW}$ and 600 MW units have been applied widely as the primary units in China. Both their high efficiency and low emission of Nitrogen Oxide (NOx) play an important role in saving energy

* Corresponding Author.

E-mail: wyb700411@163.com (J. Zhang),

Telp: +87-0912-3891372, Fax: +87-0912-3896358 and environmental protection. One of the most effective ways is to adopt low NOx combustion technologies, such as Low oxygen combustion and Air-staged combustion. In the late $80 \mathrm{~s}$, a series of high capacities units with ABB-CE technology were introduced into China [1]. Low NOx burner reduces NOx by regulating velocity of both primary air and secondary air and mixture time of pulverized coal so as to form richfuel and lean-oxygen. This technology has been applied in utility boilers [2]. Air-staged combustion processing is one of the technologies that are applied widely both at home and aboard. Its principle is that $80-85 \%$ of required air is 
firstly supplied to the primary burner so as to decrease the Oxygen supply, which reduces the thermal NO and intermediate products. Moreover, the generated $\mathrm{NO}$ is reduced into $\mathrm{N}_{2}$ in the lean-Oxygen atmosphere.

Hao [3] investigated experimentally the airstaged combustion of both the Shenmue bituminous coal and the Yangquan meager coal in a one-dimensional furnace. Both locations of staged-air and the burner pitch depends on the demand of oxygen at various periods of combustion. Wang et al. [4] analyzed numerically the effects of deep air-staged on the combustion of low volatile coal in the one-dimensional furnace. It is found that the fine pulverized coal shows the stronger reactivity and more oxygen consumption, reducing the NOx formation. Therefore, NOx emission in deep air-staged is dominated by the fineness of pulverized coal. This technology is more suitable for the highercapacity units over $600 \mathrm{MW}$, in which the overfire air accounts for $30 \%$ of overall air. However, if this technology was applied to those units less than $300 \mathrm{MW}$, the ratio of over-fire air to overall air needs to adjust to $15 \%$ [5]. Sun et al. [6] simulated numerically NOx emission of $800 \mathrm{MW}$ ultra-critical concurrent boiler with an intermediate reheat, in which the rate of over-fire air ranges between $15 \%$ and $25 \%$. They pointed out that NOx is from the initial state of combustion, in which there is reducing zone of NOx. Critical factors that affect NOx reaction rate in primary combustion zone and burnout zone are the $\mathrm{O}_{2}$ concentration and the burning rate of coke. As the burnout air rises, the NOx generation rate decreases in primary combustion zone. When the NOx reduction zone enlarges, the NOx emission reduces noticeably. The air-staged combustion processing has been applied to 2093 ton/h boiler in Jingjie power plant in Yulin, Shaanxi, China [7]. In order to reduce NOx emission, the low NOx nozzles are adopted, and over-fire air nozzles are increased. Over-fire air rate reaches $25 \%$. Compared with $350-465 \mathrm{mg} / \mathrm{m}^{3}$ of NOx emission before the reformation, it decreases by $60-70 \%$. Besides, the temperature deviation of fuel gas decreases at the outlet of the furnace. Xiao et al. [8] investigated theoretically and experimentally the effects of air-staged combustion on temperature performance in $600 \mathrm{MW}$ subcritical boiler. It is found that air-staged combustion makes the temperature at the bottom of the screen increased by $80{ }^{\circ} \mathrm{C}$ and the temperature of super-heater increased by $20{ }^{\circ} \mathrm{C}$ without regulating operation plan of boiler. By comparing two $600 \mathrm{MW}$ units with the airstaged combustion and low NOx burner, Chen et al. [9] pointed out that the air-staged technology could easily result in the lower boiler combustion efficiency, serious corrosion and slag formation. Zhou et al. [10] applied the airstaged technology to SG-420/13.7-W576 boiler. On the basis of experimental results, both the safety and economy can be improved with several techniques, such as: the reasonable air distributions to improve the burnout air ratio, the low oxygen combustion and the low NOx burner.

On the basis of above research findings, NOx generation rate is affected by fuel properties and combustion conditions when the airstaged technology is used. Fuel properties include fuel types, moisture, ash contents, and existing state of Nitrogen and coal fineness. Combustion conditions involve the ratio of fuel to air, the residence time of fuel gas after burning, the temperature in primary combustion region, the excess air coefficients, etc. These factors interact with each other. It is necessary to consider the above factors comprehensively so as to achieve an ideal effect of NOx reduction.

At the present work, NOx reduction is simulated numerically to obtain three dimensions of the flow fields, the temperature fields and the concentration fields during the air-staged combustion in 350MW units, the calculating results are analyzed.

\section{Physical Model and Computation Method}

Figure 1 shows a physical model of boiler. It's the model of the 1150 ton/h single drum reheat cycle boiler in Dalian Huaneng power plant in China. It's $14 \mathrm{~m}$ long, $12 \mathrm{~m}$ wide and $47 \mathrm{~m}$ tall. 13 layers of burners are installed at the four corners, each layer has four nozzles. The whole set of burner is composed of five layers of primary air nozzles, five layers of secondary air nozzles, one layer of oil nozzle and two layers of three-air nozzles. Sizes of each burner are shown in Figure 2.

In establishing the model, the four corners are removed in order to make the center of the furnace form four-corner tangential firing. Nozzles of the burners are simplified, and the effects of both the surface of heat transfer and other devices are neglected.

Physical model of the boiler is grid with Gambit included in fluent software. The 3.5 million of hexahedral unstructured grid were adopted. The 0.3 was given for an interval size in the spacing item. The numerical simulation is developed with fluent software. A Realizable two equations model is applied to calculating 
turbulent flowing. A P1 model is used to consider the radiation heat transfer. A discrete phase model is employed to treat with pulverized coal particle transport and an EddyDissipation is adopted for chemical reaction. High-volatile coal serves as a fuel, air works as a combustion adjutant, and the dynamic and diffusion model is adopted to simulate combustion. The simple solver with the velocitypressure coupling is employed. Boundary conditions are given, including velocity inlet and pressure outlet. The wall temperature is set at $500 \mathrm{~K}$, the temperature of primary air at $350 \mathrm{~K}$, and temperature of secondary air at $570 \mathrm{~K}$. The convergence criterion is set as 0.001 for the momentum equation, the continuity equation and species mass fraction equations. However, the convergence criterion is defined as $1 \times 10^{-6}$ for the energy equation and $\mathrm{P} 1$ radiation equations.

The formation of NOx involves the thermal and fuel NOx, but little prompt NOx. Here, only the production of $\mathrm{NO}$ was taken into account because NOx emitted into the atmosphere from the burning fuels consists mostly of $\mathrm{NO}$, with much lower concentrations of $\mathrm{NO}_{2}$ and $\mathrm{N}_{2} \mathrm{O}$. The concentration of thermal NOx is calculated with the extended Zeldovich mechanism, described in Equations (1-3).

$$
\begin{aligned}
& \mathrm{N}_{2}+\mathrm{O} \rightarrow \mathrm{NO}+\mathrm{N} \\
& \mathrm{N}+\mathrm{O}_{2} \rightarrow \mathrm{NO}+\mathrm{O} \\
& \mathrm{N}+\mathrm{OH} \rightarrow \mathrm{NO}+\mathrm{H}
\end{aligned}
$$

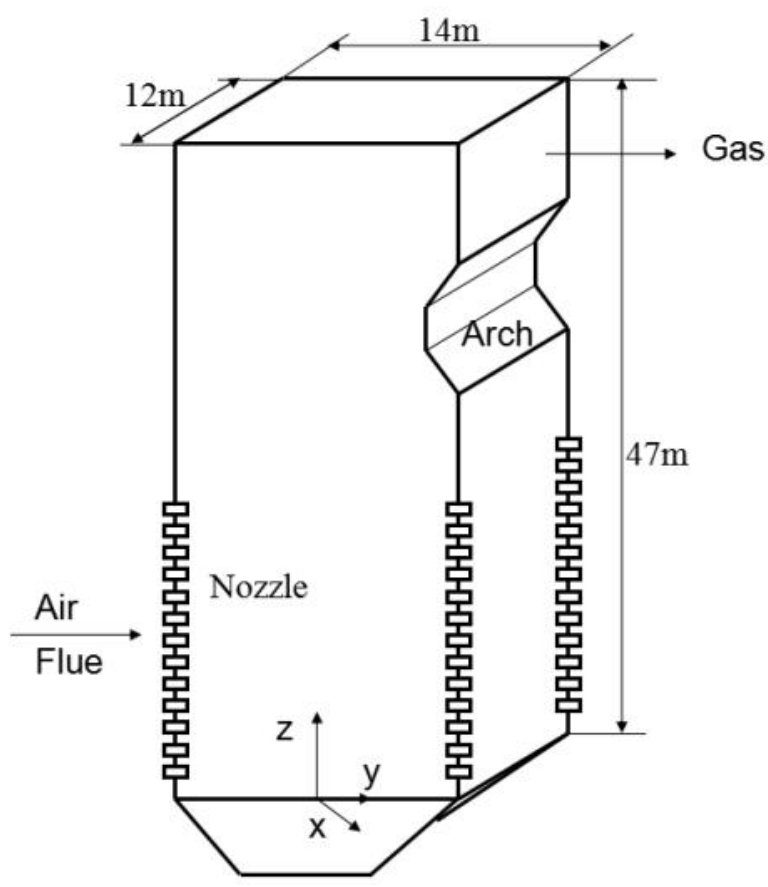

Figure 1. A physical model of boiler
The fuel NOx contributes mostly to the formation of NO about more than $75 \%$. The nitrogen content in the fuel is generally composed of volatile-nitrogen $\left(\mathrm{HCN}\right.$ and $\mathrm{NH}_{3}$ ). It is found that $\mathrm{HCN}$ is the center of the whole reaction loop. Both $\mathrm{NH}_{3}$ and $\mathrm{HCN}$ originate from the Fuel-N, and $\mathrm{NH}_{3}$ can be converted into $\mathrm{HCN}$ provided that large quantity of NO exists in the fuel-rich environment, while $\mathrm{HCN}$ can't be turned into $\mathrm{NH}_{3}$ directly. In the lean-oxygen atmosphere, $\mathrm{HCN}$ and $\mathrm{NH}_{3}$ can be reduced into $\mathrm{N}_{2}$ as described in Equations (4-5). The formation of prompt NOx was neglected in the calculations.

$$
\begin{aligned}
& \mathrm{NH}_{3}+\mathrm{NO} \rightarrow \mathrm{N}_{2}+\ldots . . \\
& \mathrm{HCN}+\mathrm{NO} \rightarrow \mathrm{N}_{2}+\ldots . .
\end{aligned}
$$

\section{Results and Discussion}

NOx emission is simulated by a computation fluid dynamics software FLUENT 6.3.26 in both air-staged and non air-staged boiler combustion. In the non air-staged combustion, two layers of three-air nozzles are removed, the velocity of secondary air is $46 \mathrm{~m} / \mathrm{s}$ and the mass flux of pulverized coal is $144 \mathrm{ton} / \mathrm{h}$. In the airstaged combustion, two layers of three-air nozzles remain and the velocity of secondary air is $35 \mathrm{~m} / \mathrm{s}$. Effects of air-staged combustion on NOx reduction at $20 \%$ of burnout air are analyzed by comparing computation parameters including temperature fields, flow fields and 
NOx concentration fields.

\subsection{Temperature fields}

Figure 3 shows temperature distributions on the transverse cross-section in the primary combustion region. This cross-section locates in the center of the whole set of burners, i.e. the outlet of third-layer nozzles; its height is 6.184 $\mathrm{m}$. It embodies the temperature performance in the primary combustion region.

As can be seen from Figure 3, the temperature along the direction of pulverized coal jet is higher in primary combustion region. This is caused by the released heat of pulverized coal ejection due to its quick ignition. However, the temperature is lower at the surroundings of the primary burners and on the furnace wall. These characteristics are attributed to the structure of the four-corner tangentially pulverized coal boiler, which is beneficial to the ignition and combustion of pulverized coal.

When the temperatures in the air-staged and non air-staged combustion are compared, it is found that higher temperature appears in the center of primary combustion region in the former while it occurs in the vicinity of burner ejector in the latter. Furthermore, when air is staged, both lower temperature deviation of fuel gas and uniform temperature can be obtained.

Figure 4 shows the temperature distributions on the longitudinal cross-section in the center of the furnace, which clearly gives an overview of temperature distributions. The temperature is higher in the primary combustion region than in other regions; the highest value appears in the vicinity of primary burner

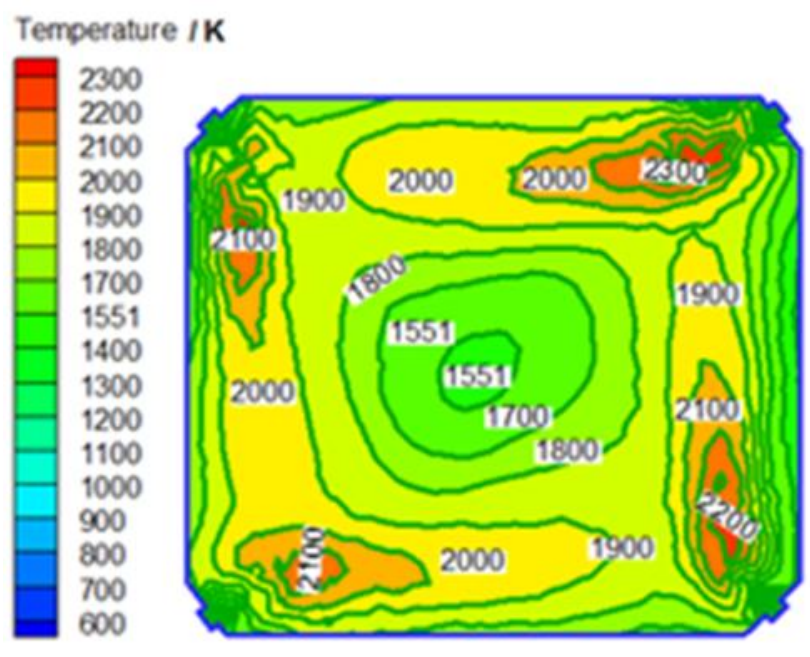

(a) No air-staged ejector. When the air is not staged, the flame is easily attached to the furnace wall and the temperature deviation of fuel gas is higher in the furnace. However, when the air is staged, the flame concentrates in the center of the furnace forms a torch and showing lower temperature deviation of fuel gas.

\subsection{Flow fields}

Figure 5 shows the velocity distributions on the transverse cross-section in primary combustion zone. Fuel gas rotates clock-wisely on the transverse cross-section in primary combustion zone, forming proper rotating velocity field, which is conducive to organizing the combustion of pulverized coal. The higher velocity appears at the outlet of the burner, while the lower velocity occurs in the center of the furnace and around the wall. When the air is not staged, the fuel gas interacts with each other intensively due to the higher secondary air velocity, easily causing the flame to attach to the furnace wall. Besides, the streamline appears approximately a circular shape while it appears an ideal tangent circle in the center and vortexes around the wall of the furnace when the air is staged. This contributes to the ignition and combustion of pulverized coal and the NOx reduction reaction.

Figure 6 shows velocity distributions on the longitudinal cross-section of the furnace. Streamline is smooth and has enough rigidity under the air-staged circumstances. However, it has poor rigidity and appears vortexes on two sides of primary combustion zone under no airstaged circumstances, which causes the flame to attach to the wall and results in higher temperature deviation of fuel gas. This is consistent

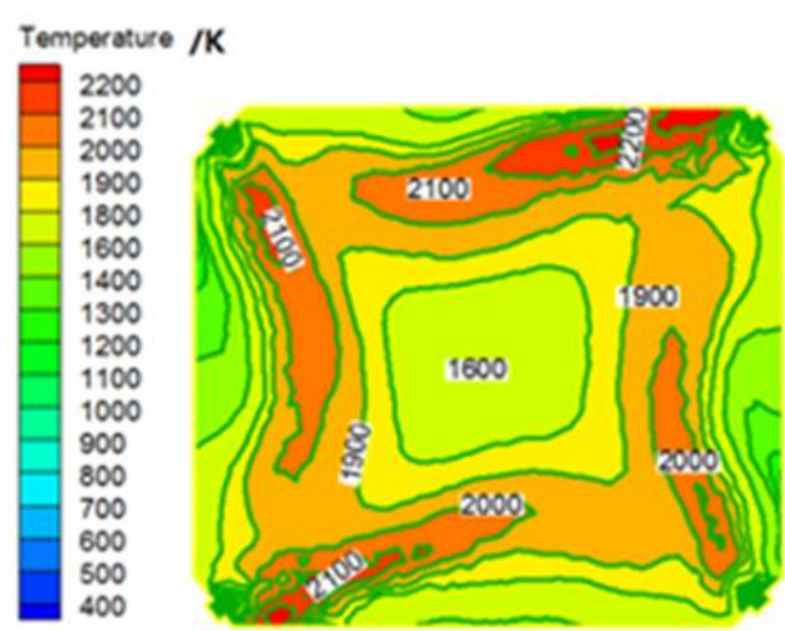

(b) Air-staged

Figure 3. Temperature distributions on transverse cross-section in primary combustion region 
with reference [8] which mentions that improving burnout air may achieve stronger rigidity streamline so as to ensure that the whole furnace is covered with flame and to regulate the deviation temperature of fuel gas.

\subsection{NO mass fraction}

Figure 7 shows NO mass fraction in the primary combustion zone for no air-staged and air-staged. NO mass fraction is higher near the outlet of the burner. This is mainly because the higher temperature and fuel concentration improve the thermal and fuel $\mathrm{NO}$ generation rate near the outlet of the burner. However, in the region far from the nozzle of the burner, lower $\mathrm{O}_{2}$ concentration contributes to the NO reduction.

Figure 8 shows the NO mass fraction on the longitudinal cross-section in primary combustion zone. NO mass fraction is higher near the outlet of the burner; it reduces along the height of the furnace. On the longitudinal crosssection, NO mass fraction is higher obviously for no air-staged than for air-staged.

\subsection{Temperature distributions and NO mass fraction at the furnace outlet}

Figure 9 shows a comparison of temperature distribution at the furnace outlet under the airstaged and the no air-staged. Compared to no air-staged, the deviation of gas temperature at the furnace outlet is smaller for the airstaged, the zone of local high temperature is narrower, the temperature distribution is more uniform, and the heat exchanger arranged at the exit of furnace will obtain more stable temperature characteristics. This is mainly because the air is given into the furnace by means of step-by-step, which makes the mixture of both the fuel and the air more uniform, the fuel burns more fully. Therefore, there are few area of local high temperature, so the stable temperature characteristics can be achieved.

Figure 10 shows NO mass fraction at the furnace outlet. Compared to the no air-staged, NO mass fraction at the furnace outlet is lower under the air-staged. This is mainly because both $\mathrm{NH}_{3}$ and $\mathrm{HCN}$ in the gas reduced obviously for the air-staged, which is caused by the fuel without sufficient oxygen. In addition, the ions of both the $\mathrm{O}$ and $\mathrm{N}$ in the gas under the air-staged are significantly decreased, which is the result of the air-staged to reduce the local high temperature of the flue gas. Therefore, the application of airstaged combustion can effectively reduce the concentration of NO emissions, improve the air quality, and promote the environmental protection.

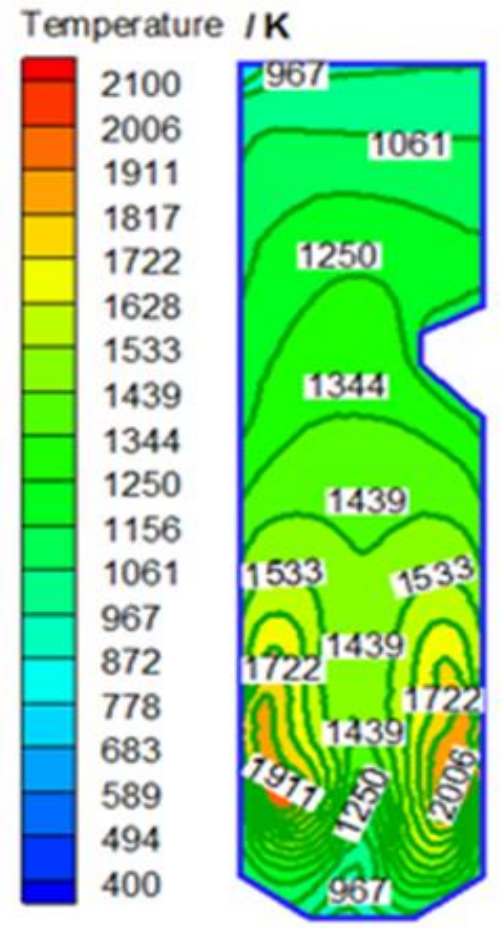

(a) No air-staged

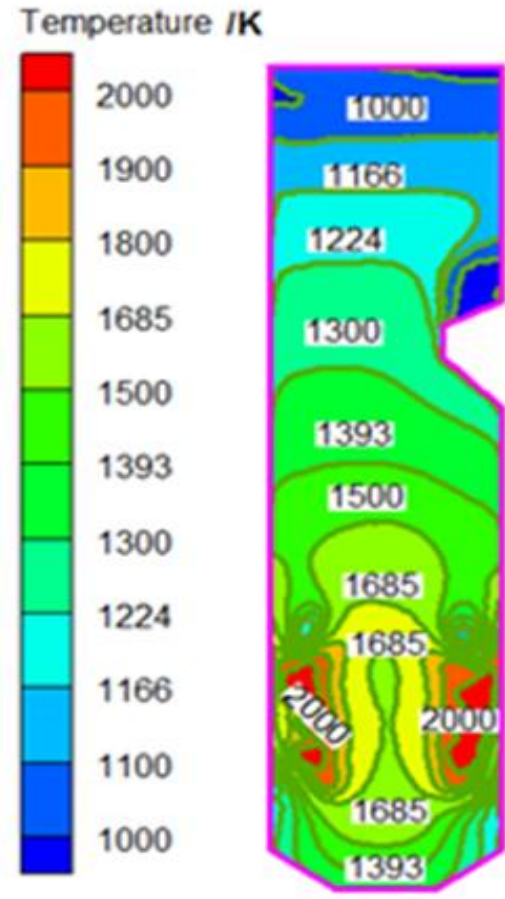

(b) Air-staged

Figure 4. Temperature distributions of longitudinal cross-section in the center of the furnace 
velocity-magnitude $/(\mathrm{m} / \mathrm{s})$
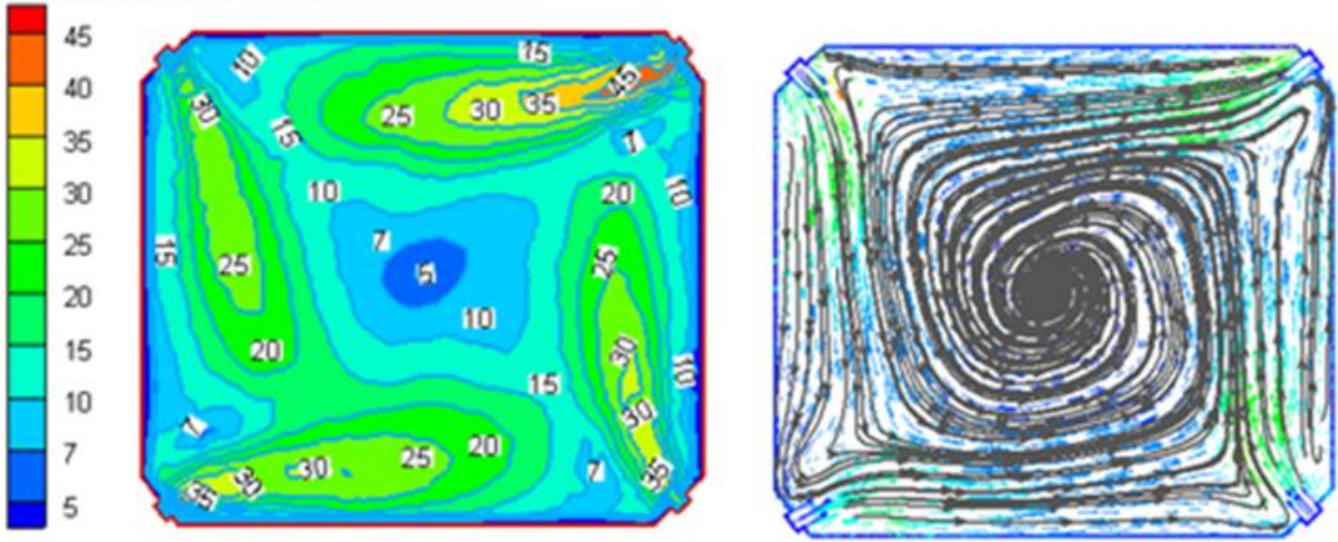

(a) No air-staged

velocity-magntude /(m/s)
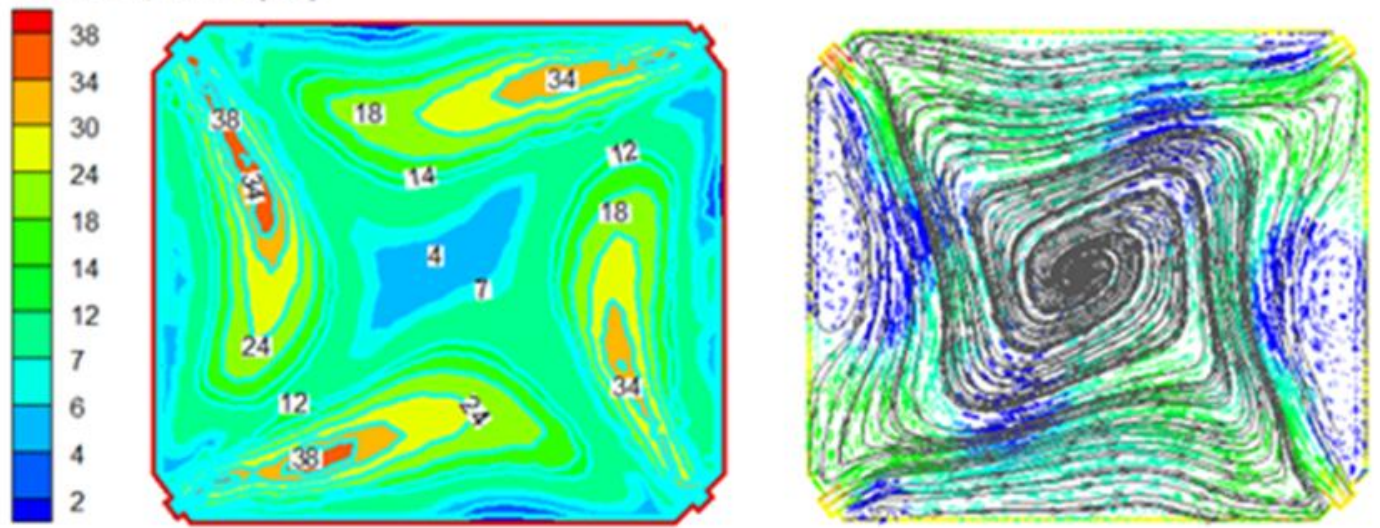

(b) Air-staged

Figure 5. Velocity distributions on transverse cross-section in primary combustion zone

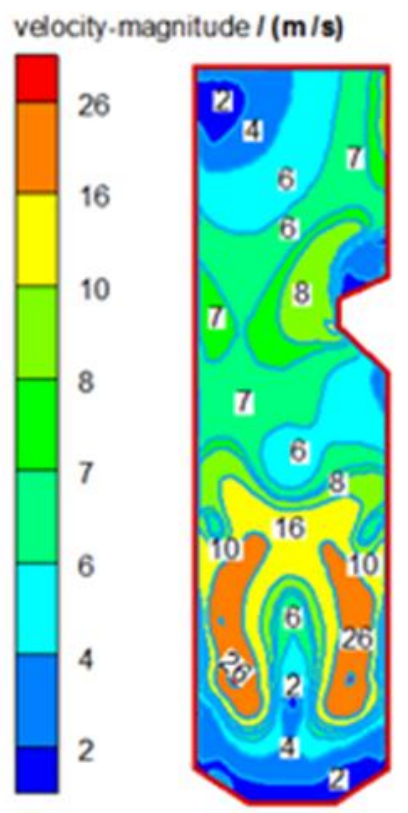

(a) No air-staged
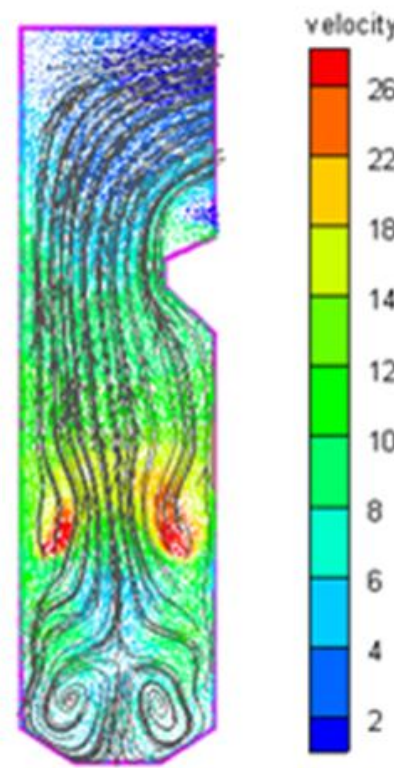

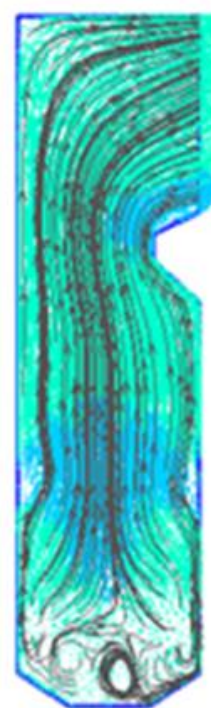

(b) Air-staged

Figure 6. Velocity distributions at longitudinal cross-section of the furnace 
NO

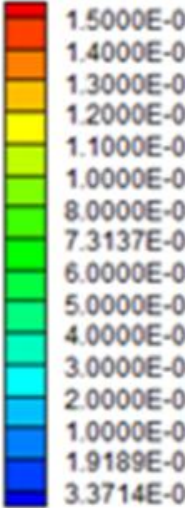

$1.5000 \mathrm{E}-03$
$1.4000 \mathrm{E}-03$
$1.3000 \mathrm{E}-03$
$1.2000 \mathrm{E}-03$
$1.1000 \mathrm{E}-03$
$1.0000 \mathrm{E}-03$
$8.0000 \mathrm{E}-04$
$7.3137 \mathrm{E}-04$
$6.0000 \mathrm{E}-04$
$5.0000 \mathrm{E}-04$
$4.0000 \mathrm{E}-04$
$3.0000 \mathrm{E}-04$
$2.0000 \mathrm{E}-04$
$1.0000 \mathrm{E}-04$
$1.9189 \mathrm{E}-05$
$3.3714 \mathrm{E}-06$

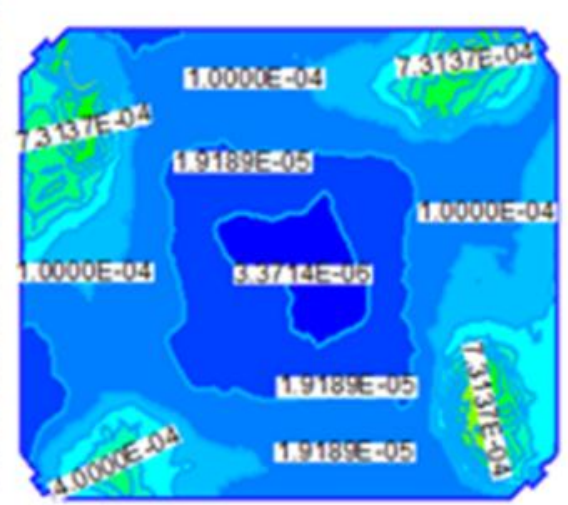

(a) No air-staged
NO

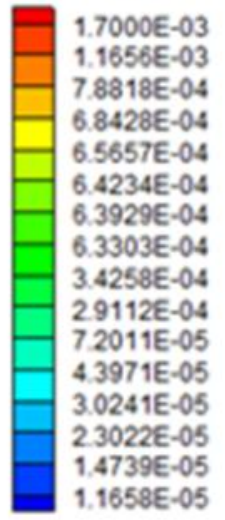

(b) Air-staged

Figure 7. Velocity distributions on transverse cross-section in primary combustion zone

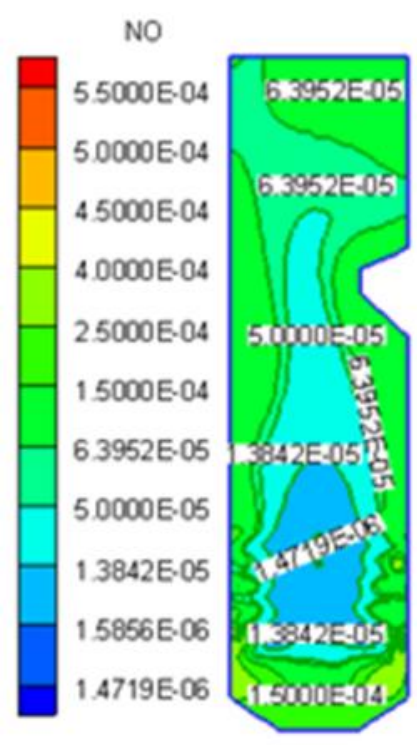

(a) No air-staged

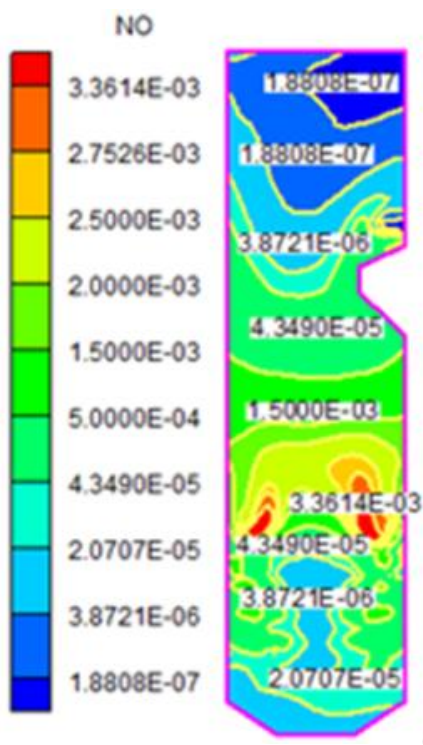

(b) Air-staged

Figure 8. NO mass fractions on the longitudinal cross-section

Temperature / $\mathrm{K}$

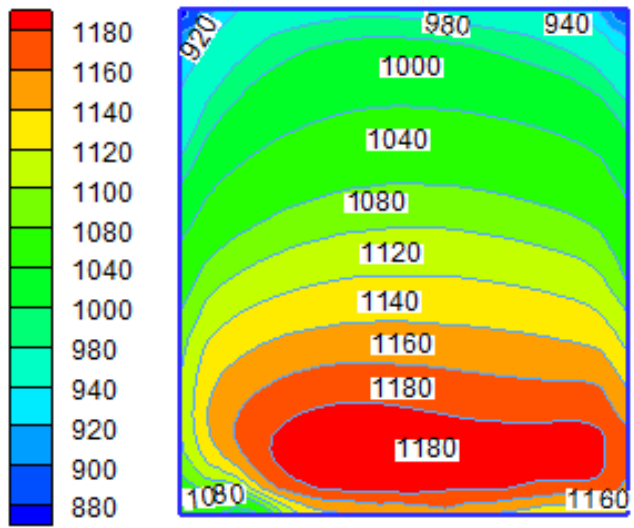

(a) No air-staged
Temperature /K
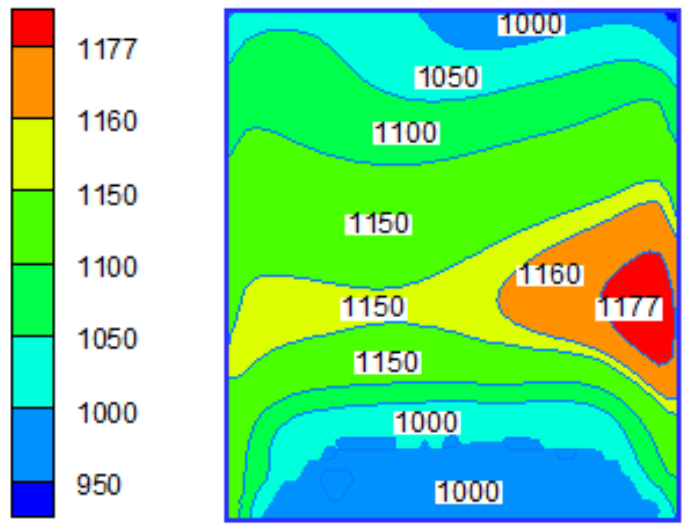

(b) Air-staged

Figure 9. Temperature distributions at the furnace outlet 


\subsection{A comparison of the present results to the calculated values in the reference}

By comparing the calculated results in this article to that of the literature [11], it found that the temperature field distribution in this article is in agreement with that under the optimal operating conditions in literature [11]. The temperature in the region near the burner is higher, and the temperature rises firstly and then reduced along the central axis of the furnace. The difference is that the temperature in the vicinity of the burner nozzle is higher than that in the literature [11], the maximum temperature is about $2000 \mathrm{~K}$, while the value in the literature is only about $1700 \mathrm{~K}$. The temperature in the literature at the burnout zone and the upper part of the furnace is higher than the simulation results in this article.

The differences between the simulation results in this article and that in the literature are caused by a reasons that is to burn different kinds of coal. In this paper, the high volatile coal in the Fluent software library is adopted. However, a kind of Northern Shannxi bituminous coal is applied in the literature. Because the high volatile coal powder is easy to be ignited as compared to Northern Shannxi bituminous coal, more heat is released quickly at the near of the burners in my paper so as to a higher temperature.

\section{Conclusions}

At the present work, NOx emission under the circumstances of air-staged combustion in the boiler is simulated numerically with the Fluent software. Various parameters, including the velocity fields, the temperature fields and NOx concentration fields, are obtained. When air-staged technology is used, flow field in the furnace have a stronger rigidity and a
NO

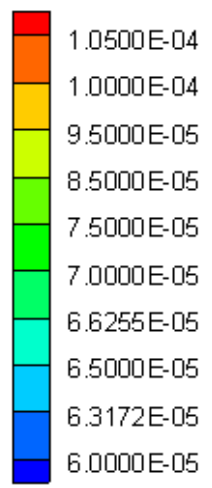

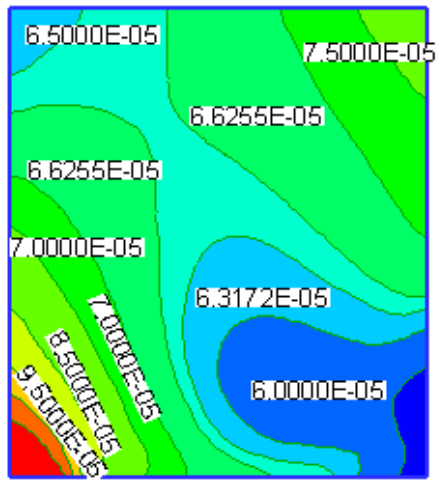

(a) No air-staged
NO

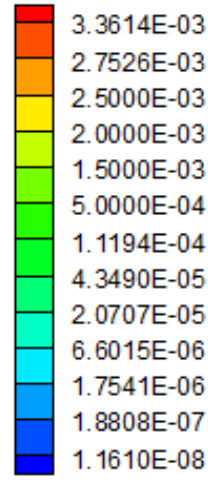

(b) Air-staged

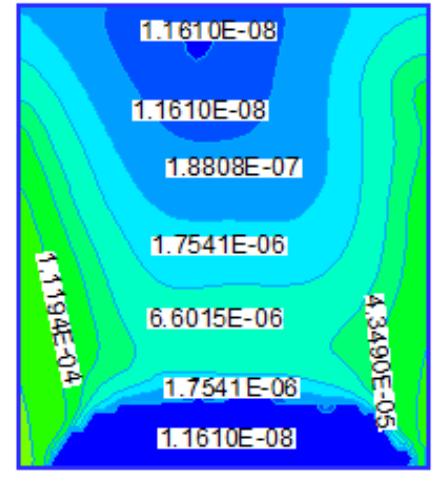

Figure 10. NO mass fraction at the furnace outlet
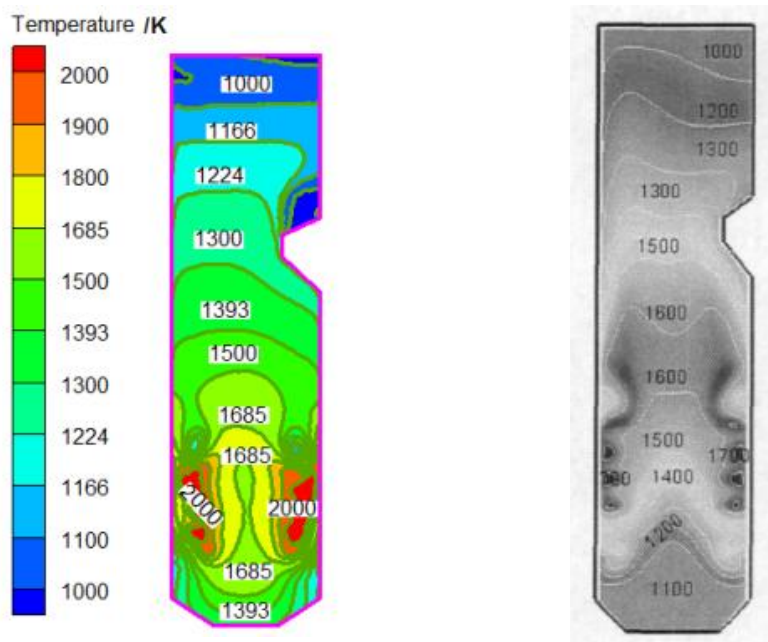

(a) Air-staged

(b) References [11]

Figure 11. A comparison of the present result with the calculated results in the reference [11] 
force of penetration. The flame is not easily declining and attached to the wall. Temperature distributes uniformly in the furnace, with the lower temperature deviation of fuel gas. Flame may form torch in the center of the furnace, with excellent performance of both convective and radiation heat transfer. NO mass fraction reduces along the direction of the height of the furnace, with lower value at the outlet of the furnace.

\section{Acknowledgment}

This work was financially supported by the industrial research Project of Shaanxi province science and Technology Department of China (Grant No. 2015GY099).

\section{References}

[1] Bi, Y.S. (1998). Application and operation of low NOx Burners in Chinese utility Boiler. Thermal Power Generation, 1: 4-13.

[2] Zeng, H.C., He, X.G. (1988). On the Combustion Technology of Large Modern Boiler. Power Engineering, 1: 12-19.

[3] Hao, X.M. (2007). Study on Two-staged Air Over-fire Technology of Staged-air Combustion Technology. Clean Coal Technology, 13(2): 70-72.

[4] Wang, H.J., Fang, Q.Y., Zhou, H.C. (2009). Study of the Influence of the Deep Air-staged Burning on a low-volatile Coal Combustion Process. Journal of Engineering for Thermal Energy and Power, 24(6): 777-781.
[5] Wang, C.C. (2010). Study on Matchability of low NOx Staged Burning Technology for air with the Boiler Capacity. Thermal Power Generation, 39(5): 6-8.

[6] Sun, B.M., Wang, D.H., Duan, E.P., Guo., Y.H., Cao., W.H., Zhang., Y.H. (2013). Investigation on NOx Formation Characteristics Under Air-staged Combustion. Power Engineering, 33(4): 261266.

[7] Zhu, J.Y., He, J.W., Yin, W.J. (2013). The modification of Double-scale low-NOx Burnerss at Boiler 3 in Jinjie Power Co. Ltd. Energy and Saving Energy, 8: 104106.

[8] Xiao, K., Gao, M., Wu, X.J., Bian, B., Zhou, W.L., Zhang, X., Chen, F., Chen, N., Zhen, L. (2012). Effect of Air-staging low NOx Combustion Technology on Boiler Steam Temperature Characteristic. Boiler Technology, 43(5): 62-65.

[9] Chen, Z.L., Yao, W., Wang, G.F. (2012). Study on safe and Economy in operation of Boilers with air-staged combustion. Thermal Power Generation, 40(12): 4-8.

[10] Zhou, J.H., Zhao, C.J., Xu, J.H., Zhou, Z.J., Huang, Z.Y., Liu, J.Z., Qi, K.F. (2010). Application of Air-staged and low NOx Emission Combustion Technology in Plant Boiler. Proceeding of the CSEE, 30(23): 1923.

[11] Meng, F.J. (2008). Numerical Simulation of Combustion and NOx Exhaust in a tangential fired Boiler. PhD Dissertation, School of energy engineering, Dalian University of Technology.

Selected and Revised Papers from The 2015 Global Conference on Polymer and Composite Materials (PCM 2015) (16-18 May, 2015, Beijing, China) (http://www.cpcmconf.org/) after Peer-reviewed by PCM 2015 and BCREC Reviewers 